\title{
A FICÇÃO AFRICANA CONTEMPORÂNEA: CONSIDERAÇÕES SOBRE A ESTÉTICA DA NARRATIVA
}

\author{
CONTEMPORARY AFRICAN FICTION: CONSIDERATIONS ON NARRATIVE \\ AESTHETICS
}

DOI: http://dx.doi.org/10.23926/RPD.2526-2149.2018.v3.n2.p418-436.id203

\section{Adilson Vagner de Oliveira \\ Professor EBTT ( IFMT). Doutor em Ciência Política. adilson.oliveira@tga.ifmt.ed u.br}

\section{Eduarda da Rosa Zanella}

Bolsista de IC do CNPq. Membro do Grupo de Pesquisa "Literaturas Africanas em perspec-tiva comparada: História, Política e Sociedade". eduardazanella@hotmail.co $\underline{\mathrm{m}}$

\section{Luana Gabriely de Almeida Campos} Bolsista de IC do CNPq. Membro do Grupo de Pesquisa "Literaturas Africanas em perspec-tiva comparada: História, Política e Sociedade". luanacampos0212@gmail.co $\underline{\mathrm{m}}$

\section{Mariana Falcão \\ Heemann \\ Bolsista de IC do CNPq. Membros do Grupo de Pesquisa "Literaturas Africanas em perspec-tiva comparada: História, Política e Sociedade". heemannmariana@gmail.co} $\underline{\mathrm{m}}$
Resumo: Este trabalho promove algumas considerações estruturais e temáticas sobre a ficção africana contemporânea. A partir da abordagem comparada, foram analisadas três obras literárias representativas do continente: Um rio chamado tempo, uma casa chamada terra (2003) de Mia Couto, Hibisco Roxo (2011) de Chimamanda Adichie e Lueji: o nascimento de um império (2015) de Pepetela. As análises apontam para algumas questões extremamente importantes para se compreender as literaturas africanas, tais como os conflitos entre a modernidade e a tradição, o papel da mulher diante da religiosidade e o patriarcado e por fim, a releitura da história nacional como mecanismo de construção de identidades.

Palavras-chave: Literaturas africanas. Ficção contemporânea. Romance.

\begin{abstract}
This paper presents some structural and thematic considerations on contemporary African fiction. From the comparative perspective, we analyzed three representative literary works from the continent: A river called time (2003) by Mia Couto, Purple Hibiscus (2011) by Chimamanda Adichie and Lueji: o nascimento de um império (2015) by Pepetela. The analysis demonstrates some issues really important to understand the African literatures, such as the conflicts between modernity and tradition, the role of women in face of religiosity and patriarchy, and finally, the reinterpretation of national history as a mechanism of building identities.
\end{abstract}

Keywords: African literatures. Contemporary fiction. Novel. 


\section{INTRODUÇÃO}

Com o objetivo de apresentar um panorama contemporâneo sobre as configurações do romance africano na atualidade, a partir de elementos de conflito como a modernidade e a tradição, o papel atual da mulher na sociedade africana e a importância da história na formação de identidades nacionais. Este trabalho propõe significativas reflexões sobre as características estruturais e temáticas de narrativas ficcionais recentes. A seleção do corpus de análise baseouse em obras ficcionais de escritores de grande destaque em seus países na atualidade, a fim de demonstrar amostras representativas de Moçambique, Angola e Nigéria. Assim, Mia Couto, Pepetela e Chimamanda consagram-se como importantes nomes no cenário literário africano e mundial.

Trata-se de uma investigação inicial sobre um conjunto de obras relevantes para se acessar o universo ficcional recente do continente. A partir do método comparado apresentado por Carvalhal (2006), o trabalho destaca algumas questões indispensáveis para se pensar a ficção africana, desde os fundamentos do romance, os mecanismos de composição e os principais temas das narrativas. Apesar de a pesquisa ter de lidar com um universo muito amplo de produções ficcionais e uma gama enorme de contextos históricos e culturais, pode-se conseguir através da abordagem comparada um quadro de aproximação comum entre as obras e estabelecer um panorama inicial relativamente significativo para os estudos literários atuais, pois é possível perceber temas recorrentes capazes de oferecer princípios prudentes de generalização investigativa. Por isso, o artigo busca apresentar sequencialmente uma discussão sobre a estética do romance como principal elemento explicativo para a ficção africana contemporânea.

Para este empreendimento investigativo, têm-se reflexões sobre o romance $U m$ rio chamado tempo, uma casa chamada terra (2003) do escritor moçambicano Mia Couto, a fim de discutir questões ligadas aos conflitos entre a tradição e a modernidade, em seguida, com o objetivo de pensar a condição da mulher e o papel das escritoras na atual sociedade africana, a obra ficcional Hibisco Roxo (2013) da nigeriana Chimamanda Adichie ocupa um espaço significativo nessa proposta de trabalho, e por fim, o romance Lueji: o nascimento de um império (2015), do escritor angolano Pepetela, funciona como uma amostra representativa das produções ficcionais em que a história nacional tende a ser revisitada com o propósito de reconhecer-se dentro de um percurso de compreensão sobre o próprio passado e a construção de identidades nacionais. 


\section{A FICÇÃO AFRICANA CONTEMPORÂNEA: A ESTÉTICA DO ROMANCE.}

A escrita ficcional tende a se atualizar a cada geração produtiva, os procedimentos poéticos, os mecanismos narrativos e os elementos composicionais e temáticos, surgem como alternativas de sustentação aos projetos literários emergentes, especialmente no romance (CHAVES, 1999; KUNDERA, 1998; LUKÁCS, 2000; WATT, 2010; BAKHTIN, 2010). Trata-se, portanto, de transformações necessárias para que as produções literárias possam acompanhar a dinâmica da realidade objetiva, por isso, a crítica literária se retroalimenta dessa matéria poética, em constante fenômeno de inovação, a fim de compreender as configurações do mundo atual.

Assim, pode-se afirmar que a dinamização da história literária reflete as novas formas de se perceber o homem em sua individualidade e universalidade, dualidade pertinente às experiências poéticas modernas que se converteram em reflexões psicológicas de introspecção, análises sociais e históricas, além de questionamentos filosóficos que abarcam as condições existenciais e as tragédias do cotidiano social. E para representar todas estas formas de pensamentos, o romance passa a se comunicar constantemente, não somente, com outros gêneros literários, mas também com outras expressões de arte e eventos históricos (OLIVEIRA, 2014a).

Numa tentativa de revelar a complexidade dos fenômenos do mundo, o romance toma constantemente novas formas, a partir de estéticas híbridas e discursos polifônicos que disputam um espaço no horizonte ficcional e também na sociedade. O diálogo entre as artes e a história surge como um meio alternativo de compreender o mundo, revisitando o passado para tentar entender as consequências e os desdobramentos das ações humanas agora no presente. Nessa perspectiva, a memória adquire um valor fundamental de resgate das experiências do passado, com todas as suas falhas e ausências, mas torna-se uma fonte de criação constante.

Para Fisher (1983, p.13) “a arte é o meio indispensável para essa união do indivíduo com o todo; reflete a infinita capacidade humana para a associação, para a circulação de experiências e ideias", em termos objetivos, este princípio interacional entre arte e sociedade se constrói através dessa constante busca de si mesmo na vivência do outro, na tentativa de compreender-se dentro da complexidade dos fenômenos humanos e sociais do cotidiano. Por meio da realidade ficcional, as questões se colocam como elementos norteadores para a escrita, longe de tentar explicitar respostas, a ficção sintetiza as incompreensões humanas face às adversidades e às tragédias da existência. 
O romance pôde produzir mecanismos para descobrir, a partir de suas próprias características de expressividades, seguindo sua própria lógica criativa, os diferentes aspectos da existência (KUNDERA, 1988). Dessa maneira, as incertezas sobre a própria existência humana e sobre os fenômenos do mundo social convertem-se em matéria narrativa, dialógica e flexível diante das proposições inovadoras dos indivíduos. Em outras palavras, os fluxos da realidade não podem ser comandados ou ordenados pelos indivíduos em sua totalidade, uma vez que os desdobramentos das escolhas individuais podem gerar eventos imprevisíveis, cujo controle escapa das mãos do herói. No final, o triunfo pode não acontecer, o herói pode renderse diante dos primeiros obstáculos, o diálogo poder não mais existir, convertendo-se em apenas vozes interiores de caráter crítico.

Nessa perspectiva, as tragédias históricas são processadas pela literatura, servindo como lastros materiais para a elaboração criativa, porém, não se pode desconsiderar o fato de que o discurso histórico já é constituído por contingentes pertencentes a tempos diversos, pois, "viver é conviver com épocas distintas" (COSTA LIMA, 2006, p.131). Assim, os elementos trágicos da história se processam com as reconstruções individuais da memória, a fim de produzir resultados híbridos e extremamente dialógicos entre os eventos da realidade e da ficção. As referências históricas das literaturas africanas funcionam como procedimentos de atualização da escrita literária, conectando os eventos individuais do cotidiano com os fatos históricos recentes.

A literatura, como processo artístico, sempre forneceu ferramentas fundamentais para se compreender a sociedade em diferentes épocas da produção literária mundial. O caráter social da literatura encontra-se exatamente nessa capacidade de transmitir elementos exteriores às obras, cujas dimensões perpassam os campos sociais, culturais, históricos, políticos e filosóficos. Ao refletir sobre o estudo da condição humana, Morin (2000) destaca o papel das produções artísticas, em especial, a literatura como fundamental para demonstrar a contribuição do romance ao conhecimento humano contemporâneo, as áreas de cultura humanística de formação apresentam elementos que colaboram para a reflexão sobre o indivíduo e sua sociedade, o que exige cada vez mais a constante tentativa de compreensão do outro e a consciência da complexidade do homem e de suas ações.

O papel das produções culturais para o autor se apresenta como uma rica contribuição para esse exercício de reflexão sobre a condição humana e principalmente sobre sua complexidade. O caráter existencialista e subjetivo das personagens do romance reflete as crises interiores e interage com um ambiente que dialoga com seus pensamentos. Já que os indivíduos 
tendem atualmente a permanecer cada vez mais fechados aos outros, essas obras podem favorecer o uso intenso da subjetividade e nos mostram as relações do ser com o outro, com a sociedade e com o mundo.

O romance é mais que um romance. Sabemos que o romance, a partir do século XIX, tornou-se prenhe de toda a complexidade da vida dos indivíduos, até da mais banal das vidas. Ele demonstra que o ser mais insignificante tem várias vidas, desempenha diversos papéis, vive uma existência em parte de fantasias, em parte em ações (MORIN, 2003, p.44).

É a literatura que possui este poder, pois cada personagem carrega em si uma complexidade de seres e de elementos que foram compostos por multiplicidades interiores e exteriores. O trabalho estético social e existencial do qual as artes se utilizam conduz as pessoas ao contato com o mistério e com a fantasia, além de fazê-las defrontar-se com a própria história nacional. E o princípio de que a arte imita e vida e a vida imita a arte demonstra que em toda grande obra de literatura, de cinema, de poesia, de música e de pintura há uma reflexão profunda sobre a existência humana.

\section{QUESTÕES DE IDEOLOGIA E DISCURSO NA ANÁLISE DO ROMANCE AFRICANO}

Para Reuter (2004, p.37), "todo fato linguístico pode ser analisado segundo dois aspectos: o de um enunciado, produto acabado e fechado ou o de uma enunciação, ou seja, o ato de comunicação que o gerou”. Dessa forma, o princípio de que alguém produziu um enunciado para outra pessoa em um tempo e lugar específicos é evidente, e que houve uma intenção determinada para esta produção. Portanto, fica à tona o princípio da obra sempre inacabada, o fenômeno da enunciação tende a ser constante nas produções literárias, a tríade autor-obra-público (CANDIDO, 2010) se realiza somente após o efeito causado por essa relação, as modificações alcançadas pela obra no público leitor. Partindo desta premissa que descreve o fato linguístico, tem-se a ideia que as produções literárias seguem este princípio de tempo, espaço e intencionalidade.

[...] retornam incessantemente as questões da abertura ou do enclausuramento do romance em relação ao mundo exterior, da responsabilidade do escritor, dos poderes da escrita literária, de sua capacidade de dar conta do real e das novas formas a serem encontradas, a fim de dar conta dos descaminhos do mundo (REUTER, 2004.p. 18).

Surge assim, um questionamento acerca do nível de engajamento do autorlobra com estes fatores externos descritos pela autora, o quanto a produção literária será moldada pela exterioridade. Dado o fato que a literatura é também um fato social (CANDIDO, 2010), percebe-se cada vez mais, que as reflexões produzidas sobre as obras literárias devem levar em conta fatores mais profundos e complexos que tempo e espaço, surge a necessidade de se 
estabelecer parâmetros não somente estéticos, mas também discursivos e ideológicos para se atingir a complexidade analítica ideal. Pois, como descreve o próprio autor, uma tendência comum é de "analisar o conteúdo social das obras, geralmente com base em motivos de ordem moral ou política" (CANDIDO, 2010, p.29), ou seja, verificar superficialmente as características da sociedade na época de produção da obra, sem necessariamente, realizar uma reflexão sobre o quanto isto afetou a estruturação e a estética da obra, o quanto a questão espaço e tempo pôde demonstrar-se como uma força ideológica que moldou personagens e enredo sutilmente.

Assim, a primeira tarefa é investigar as influências concretas exercidas pelos fatores socioculturais. É difícil discriminá-los, na sua quantidade e variedade, mas pode-se dizer que os mais decisivos se ligam à estrutura social, aos valores e ideologias, às técnicas de comunicação (CANDIDO, 2010, p.31).

Essa força ideológica transpassa o escritor, sem que o próprio tenha consciência desse patrimônio cultural coletivo que molda a estética, a estrutura, a temática e as personagens de seu trabalho. Abdala Junior (2007, p.45) explicita ainda que "quando o escritor escreve, pode julgar que o texto é apenas seu, não tendo consciência de que na verdade é a sociedade que se inscreve através dele", em resumo, essa apropriação ultrapassa a consciência do sujeito, está tão intrínseca a ele que sua autoria, a princípio se parece única, mas em realidade foi influenciada por forças coletivas constantes em seu espaço e tempo. O efeito inconcluso característico das produções literárias é conseguido através do pensamento dialético que perceba este objeto numa totalidade, porém, numa totalidade aberta, em constante construção.

As produções dessa literatura engajada descrita pelo autor se aproximam dos processos de apropriação ideológica, até então, ocultas pelas análises e releituras. Isso conduz aos pressupostos teóricos pertencentes ao campo de alcance do conceito ideologia.

Fiorin (2003, p.28) elucida este conceito descreve que "a partir do nível fenomênico da realidade, constroem-se as ideias dominantes numa dada formação social”, e por passarem por processos de racionalização pelas classes dominantes, apresentam-se como verdades que explicam e justificam a realidade, conseguindo assim, correr livremente na consciência coletiva, mesmo que seja através de uma aparente individualidade conceitual.

A esse conjunto de ideias, a essas representações que servem para justificar e explicar a ordem social, as condições de vida do homem e as relações que ele mantém com os outros homens; é o que comumente se chama ideologia (FIORIN, 2003, p.28)

Portanto, tem-se o conceito ideologia como o conjunto de ideias, como maneiras de pensar compartilhada pela sociedade, como formas de consciência (ideias) coletiva. O que na literatura representa uma força constante nas produções, e como estas representações da 
realidade são percebidas pelo público leitor é o desafio para os leitores e analistas. Abdala Junior (2007) em seus apontamentos sobre o lugar da ideologia na literatura acrescenta que:

Importa também destacar que a ideologia tem significação literária por sua objetivação, materialização, nas interações com os discursos culturais, cujas tensões modelam a escrita. Dessa maneira, ao impregnar a cultura de sua dimensão situacional (e das aspirações dessa situação), histórica, a ideologia o faz não apenas em relação a aspectos explícitos da modelização literária, mas também em relação aos implícitos, como acontece com os inerentes à natureza da comunicação artística (ABDALA JUNIOR, 2007, p.57).

Todos estes fatores são extremamente relevantes quando se percebe que os indivíduos, no caso específico da literatura, os tipos criados para dar sustentação aos personagens, são resultantes da interação de várias vozes ideológicas materializadas por meio do discurso a ser desvendado. E a linguagem, como objeto dessas representações, tende a cristalizar e refletir as atividades sociais de alguma forma. Como aponta Fiorin (2003, p.54) "a linguagem cria uma visão de mundo na medida em que impõe ao indivíduo uma certa maneira de ver a realidade, constituindo sua consciência”. É preciso considerar que os pontos de vistas têm sempre um caráter subjetivo, portanto, são totalmente parciais em sua ótica, fato que conduz a uma demonstração de realidades de maneira diferente e influenciadas exteriormente.

Portanto, é pertinente destacar que estas estratégias discursivas comuns à prática comunicativa representada nas produções literárias contêm em partes visões de mundo as quais veicula, e um completo sistema de valores e discursos que sustentam o comportamento das personagens e as ações desenvolvidas ao longo do enredo.

\section{UM RIO CHAMAdo TEMPO, uMA CASA CHAMAdA TERRA DE Mia COUTO}

No romance Um rio chamado tempo, uma casa chamada terra (2003) de Mia Couto, há vários temas que são discutidos, como religiosidade, tradição, memórias e a modernidade, (LEITE, 2003; MAQUEAA, 2010; PETROV, 2014; PONTES, 2014) fazendo assim com que cada personagem se encaixe nas discussões propostas, com seus dramas pessoais, como o personagem principal Marianinho, um estudante universitário que há muito tempo não visitava mais a ilha onde costumava morar, chamada Luar-do-Chão e só o faz agora porque é convocado a fazer as honras fúnebres de seu avô, o que não entende, pois quem deveria fazer isto seria seu tio Abstinêncio, por ser o filho mais velho de Dito Mariano, seu avô.

O personagem protagonista ao chegar em Luar-do-Chão percebe que há outros motivos para ter voltado, como retomar a harmonia da família, valorizar o território e reafirmar as tradições, além da cerimônia fúnebre de seu avô que está em um estado peculiar às tradições locais, pois, "o falecido estava com dificuldades de transição, encravado na fronteira entre dois 
mundos" (COUTO, 2003, p.41). Para Maquêa (2010), a própria composição do tempo e do espaço na narrativa de Mia Couto está conectada à construção de Moçambique, assim, o produto ficcional acaba por colocar em cena o passado colonial, os conflitos históricos por libertação e a natural busca por uma expressão moçambicana para essa literatura.

Segundo Leite (2003), a própria divisão em vinte e dois capítulos, construídos de forma a organizar a narrativa, faz com que os contos possam ler lidos livremente, porém, possuem um elo de conexão importantíssimo para transformar as narrativas isoladas em um romance. Por meio de cartas misteriosas destinadas a ele, percebe os reais motivos da necessidade de sua presença na ilha, como se pode observar no trecho:

Estas cartas, Mariano, não são escritos. São falas. Sente-se, se deixe em bastante sossego e escute. Você não veio a esta ilha para comparecer perante um funeral. Muito ao contrário, Mariano. Você cruzou essas águas por motivo de um nascimento. Para colocar o nosso mundo no devido lugar. Não veio salvar o morto. Veio salvar a vida, a nossa vida. Todos aqui estão morrendo não por doença, mas por desmérito do viver (COUTO, 2003, p.64).

Assim, pode-se dizer que ao narrar a história dos outros personagens e de si mesmo, Marianinho relata sobre a história também de uma África que tende a perder seus vínculos com a ancestralidade, através mesmo da condição insólita do avô que se encontra em condição suspensa entre a vida e a morte, o passado do país é defrontado com os novos dilemas póscoloniais (MAQUEAA, 2010). O avô de Marianinho conversa com ele por meio dessas cartas que se transformam no fio condutor com o passado, com a tradição, assim, Mariano torna-se o encontro entre a modernidade com a tradição, pois mora há muito tempo fora da ilha e assim absorveu a cultura da cidade (PONTES, 2014; PETROV, 2014). Em contrapartida, seu retorno à ilha representa a união cultural de seu avô tradicionalista com a de Marianinho modernista e também a tentativa de reconstruir as memórias daquela família. Este encontro faz com que ele tenha de fazer renascer a ilha de Luar-do-Chão que está em uma situação de enfraquecimento e desamparo e a harmonia de seus familiares que enfrentam seus dramas pessoais.

De acordo com Maquêa (2010, p.122), “a lembrança é uma cicatriz que voltará a sangrar acontecimentos do passado na vida de toda uma família, da comunidade da ilha e mesmo do país inteiro". Os mistérios da ilha incompreendidos pelo protagonista refletem, de certa maneira, a incompreensão do país diante de sua própria história ainda carente de reflexões e versões, uma vez que a escrita da história per se já exige o acesso às verdades do discurso sobre o passado.

Com ajuda das pistas que são dadas nas cartas, Mariano percebe que existem muitos segredos a serem desvendados e enquanto ele não os compreender plenamente, seu avô não 
conseguirá terminar sua trajetória, pois a terra se fecha para ele em consequência de sua vida mal vivida. Como pode ser observado no trecho:

O coveiro decide abrir uma cova mais ao lado. Um rumor percorre os presentes. Curozero, transpirado, afasta-se uns passos e recomeça a batalha contra o chão. Em vão. Também ali surge, à flor da terra, uma pedra intransponível (COUTO, 2003. p. 178).

Marianinho começa a entender o que seu avô disse na carta em relação à vida e à morte, a partir de suas reflexões sobre as experiências culturais e metafísicas tidas no lugar de retorno, através do contato com os familiares e as cartas do avô. Nessa perspectiva, a epígrafe do primeiro capítulo anuncia: "encheram a terra de fronteiras, carregaram a céu de bandeiras. Mas só há duas nações - a dos vivos e a dos mortos" (COUTO, 2003, p. 13), uma importante tomada de consciência sobre efemeridade da vida em contraposição aos conflitos políticos e sociais das personagens. Trata-se de um ensinamento da tradição, assim repassado pelo avô Dito Mariano.

Marianinho também carrega o nome de seu avô e com isso carrega sua ancestralidade que, nas palavras de Pontes (2014, p.7) "na cultura moçambicana os ancestrais são vistos com respeito, porque eles carregam a cultura, tradições do povo". Mariano também tem valores da cidade, mas continua a se dedicar a sua tradição após seu retorno à ilha. Desse modo, a constante oscilação entre os valores ligados à tradição africana e a modernidade produz na imagem do personagem uma relação de identidade e alteridade que reflete um percurso existencial e histórico (PETROV, 2014).

Outro tema a ser discutido é a ambição, retratada na imagem de seu tio Ultimío que quer comprar a Nyumba-Kaya e há uma discussão entre ele e Marianinho, pois se ele comprar a casa, assim, estará negando as memórias e consequentemente, negando as tradições. Esta discussão pode ser observada no trecho a seguir:

- Vou. Mas volto logo para tratar da compra de Nyumba-Kaya.

- O tio não entendeu que não pode comprar a casa velha?

- Pois, escute bem, eu vou comprar com meu dinheiro. Essa casa vai ser minha.

- Essa casa nunca será sua, Tio Ultímio.

- Ai não?! E por quê, posso saber?

- Porque essa casa sou eu mesmo. O senhor vai ter que me comprar a mim para ganhar posse da casa. E para isso, Tio Ultímio, para isso nenhum dinheiro é bastante (COUTO, 2003. p. 249).

A metáfora da casa, como referência direta à terra, à propriedade em sua característica mais inegociável, diante dos costumes ocidentais de transacionar qualquer elemento disponível na terra. Assim, o espaço defendido pelo personagem Marianinho converte-se numa reflexão 
política sobre a história de Moçambique e de todos os conflitos consequentes pelo poder local e pelo domínio do território. Torna-se difícil discutir o material literário, sem a profunda associação ao fato histórico do país, pois a materialidade do texto se encontra exatamente nos paralelos dialógicos em que o romance se coloca.

Há também outros elementos, como o rio que representa o tempo e casa chamada Nyumba-Kaya "Nyumba", a palavra para nomear "casa" nas línguas do norte. No idioma do sul, casa se diz "Kaya" (COUTO, 2003, p. 28), referindo-se a um símbolo de cultura, de abrido, que para os Malilanes que de modo aportuguesado significa Marianos, tem sentido de familía e a terra que tem de assegurar a proteção dos mortos, e manter os corpos dos ancestrais (PONTES, 2014).

\section{A visão feminina na narrativa de Chimamanda Ngozi Adichie}

O romance Hibisco roxo (2011) da escritora nigeriana Chimamanda Ngozi Adichie, tem como principal enfoque questões sociais, tais como o patriarcado, a violência, o autoritarismo e a intolerância religiosa, além de crises políticas, como plano de fundo (GOMES, 2013; IFECHELOBI, 2014; CAMPOS, 2015; ANN, 2015; MÜLLER, 2017). A obra é um relato da vida da adolescente Kambili e de sua família, a qual se encontra em uma condição social elevada se comparada aos outros habitantes da região. A história se passa na Nigéria e a narrativa é feita pelos olhos de Kambilli, uma garota de 15 anos de idade que vive com o pai, a mãe e o irmão. Eles têm um padrão de vida alto, algo dificilmente esperado pelas pessoas quando se fala no continente africano.

O silêncio era quebrado apenas pelo zumbido do ventilador de teto que cortava o ar parado. Embora nossa espaçosa sala de jantar desse numa sala de jantar ainda maior, eu me senti sufocada. As paredes pintadas de bege com as fotos emolduradas do vovô estavam se estreitando sobre mim. Até a mesa de vidro se movia em minha direção (ADICHIE, 2011, p.14).

Seu pai é heroicizado desde o início do enredo, sendo classificado como homem correto e justo, além de ser extremamente religioso, desenvolvendo assim uma forma autoritária de governar seu lar de acordo com os preceitos cristãos, para que dessa maneira pudesse alcançar o respeito e a submissão de todos de sua família.

Papa se sentava todas as vezes no banco da frente para assistir à missa, na ponta que dá para a nave, com Mama, Jaja e eu junto dele. Era o primeiro a receber a comunhão. A maioria das pessoas não se ajoelhavam para receber a hóstia no altar de mármore, perto da qual ficava a estátua loura em tamanho real da Virgem Maria. Mas papa, sim. Ele fechava os olhos e apertava com tanta força que suas feições se contorciam numa careta. Ele esticava a língua o máximo que podia (ADICHIE, 2011, P.10). 
A imagem da personagem Beatrice representa o tipo de mulher que se submete ao marido em nome dos valores familiares, até mesmo sofrendo agressões ou vendo seus filhos serem agredidos frequentemente, na concepção do pai, por cometerem algum tipo de transgressão religiosa. Contudo, trata-se também do modelo de superação e transformação diante de situações de opressão e violência, pois será dela a grande responsabilidade pela mudança de trajetória dos personagens agredidos.

\begin{abstract}
Anos antes, quando eu ainda não entendia, eu me perguntava porque ela limpava as estatuetas sempre depois de eu ouvir aquele som vindo do quarto deles, um som que parecia de alguma coisa batendo na porta pelo lado de dentro. Os chinelos de borracha de Mama não faziam barulho nos degraus, mas eu sabia que ela havia ido lá para baixo quando ouvia a porta de jantar sendo aberta. Eu descia e a via parada ao lado da estante de vidro com um pano encharcado de água e sabão. Ela dedicava pelo menos quinze minutos a cada estatueta de bailarina. Nunca havia lágrimas em seu rosto. Da última vez, há apena duas semanas, quando seu olho inchado ainda estava de cor pretoarroxeada de um abacate maduro demais, Mama rearrumara as estatuetas depois de limpá-las (ADICHIE, 2011, p.17).
\end{abstract}

Por terem esse status mais elevado, Jaja (o irmão) e Kambilli não estão familiarizados com a forma que as pessoas comuns vivem. Eles têm motorista particular, escola privada e nunca passaram fome, diferentemente de sua tia e de seu avô que vivem em uma realidade completamente diferente.

Mais tarde naquela manhã, quando saímos de carro de nossa propriedade, eu me virei para permitir que meus olhos passassem, mais uma vez, pelas pilastras e muros brancos e cintilantes de nossa casa, pelo perfeito arco de água que o chafariz fazia (ADICHIE, 2011, p.70).

Entretanto essas regalias não eram boas em todos os aspectos, visto que não possuíam liberdade de pensamentos ou ações, já que acabavam sendo superprotegidos, ou seja, eram impedidos de manter muito contato com o mundo externo, o que segundo Papa propiciava oportunidades ao pecado.

- Kimbili e Jaja, hoje à tarde vocês irão à casa de seu avô visitá-lo. Kevin vai levá-los. Lembrem, não comam nada nem bebam nada. E como sempre, vão ficar só quinze minutos. Quinze minutos.

- Não gosto de mandar vocês à casa de um pagão, mas Deus vai protegê-los - disse Papa (ADICHIE, 2011, p. 67-68).

Conforme descrito pela adolescente, durante a narrativa, ocorrem atos violentos que partem de Papa, quando algum de seus princípios e regras foram quebrados pelos membros de sua casa, devido a espécie de patriarcado que vivenciam. Tais como ocorre com Beatrice - mãe de Kambili - que acaba sofrendo um aborto após ser espancada pelo marido Eugene.

Pancadas pesadas e rápidas na porta talhada à mão do quarto dos meus pais. Imaginei que a porta estivesse emperrada e que Papa estivesse tentando abri-la. Se imaginasse aquilo sem parar talvez virasse verdade. Eu me sentei, fechei os olhos e comecei a 
contar. Contar fazia o tempo passar um pouco mais rápido, fazia com que não fosse tão ruim. Às vezes, acabava antes de eu chegar ao número vinte. Eu já estava no dezenove quando o som parou. Ouvi a porta se abrindo. Os passos de Papa na escada pareceram mais desajeitados que o normal.

Saí do quarto no mesmo segundo que Jaja saiu do dele. Ficamos no corredor vendo Papa descer. Mama estava jogada sobre seus ombros como os sacos de juta cheios de arroz que os empregados da fábrica dele compravam aos montes na fronteira com Benin.

-Tem sangue no chão - disse Jaja. -Vou pegar a escova no banheiro.

Limpamos o filete de sangue, que fez uma trilha no chão como se alguém tivesse carregado uma jarra furada de tinta vermelha lá para baixo (ADICHIE, 2011, p.39).

Após Eugene sofrer ameaças relacionadas às críticas políticas publicadas em seu jornal, resolveu enviar seus filhos para permanecer alguns dias na casa sua irmã Ifeoma, uma professora universitária que resiste às imposições do governo e luta pelo que acredita. Dessa forma, Kambili consegue escapar da prisão doutrinária que existia em sua casa, nesse período eles desfrutam de uma liberdade não conhecida anteriormente.

Em outro momento, as vítimas das violências provocadas por Papa são seus filhos, Jaja e Kambili, por terem contraposto às normas religiosas que lhes foram estabelecidas, de que não poderiam dormir na mesma casa que um pagão, no caso seu avô que mudou para a casa de Ifeoma por ter adoecido, e para pagarem as consequências de suas escolhas e mentiras, Papa os coloca na banheira e joga água fervendo em seus pés, para que fossem purificados de seus pecados.

Papa baixou a chaleira dentro da banheira e inclinou-a na direção dos meus pés. Derramou água quente nos meus pés, lentamente como se tivesse fazendo uma experiência e quisesse ver o que ia acontecer. Estava chorando, as lágrimas jorrando por seu rosto. Vi o vapor úmido antes de ver a água sair da chaleira, fluindo quase que em câmera lenta, fazendo um arco no ar até chegar aos meus pés. A dor do contato foi tão pura, tão escaldante, que não senti nada por um segundo. Então comecei a gritar (ADICHIE, 2011, p.207).

Diante disso, vendo-se impossibilitada de contrapor indiretamente às ações de seu marido, Beatrice começa a envenená-lo aos poucos, para ver-se livre de toda a opressão e sofrimento que ela e seus filhos passavam em seu próprio lar. A morte de Eugene chega e com ela a prisão do irmão Jaja para proteger a mãe.

Mama amarrou melhor a canga, foi até as janelas; abriu as cortinas e verificou se os basculantes estavam fechados, impedindo que a chuva entrasse na casa. Seus movimentos eram tranquilos e lentos. Quando ela falou sua voz também estava tranquila e lenta.

-Comecei a colocar o veneno no chá dele antes de ir para Nuskka. Sisi arrumou-o para mim; o tio dela é um curandeiro poderoso (ADICHIE, 2011, p.305).

Alguns anos se passam até que Jaja, que se diz culpado do envenenamento para proteger sua mãe, se vê livre, tanto da cadeia, quanto da repressão de seu pai, prontos para recomeçar 
uma nova vida e desfrutar da liberdade que tanto sonhavam. Dessa maneira, pode-se observar que a narrativa traz uma reflexão acerca do patriarcado imposto na sociedade, e por muitas vezes cultivado pelas religiões, criando uma espécie de hierarquia domiciliar, o qual transforma a mulher em alguém que deve submeter-se ao marido.

\section{A releitura da história em Lueji: o nascimento de um império de Pepetela}

A partir de um ousado projeto literário formado por inúmeros focos temáticos, o texto ficcional de Pepetela transita em profundas discussões de caráter histórico, político e cultural (CHAVES, 2005; CHAVES e MACEDO, 2009; DRNDARSKA e MALANDA, 2000). Nutridas pela esperança na concretização social, cultural e política de Angola, as obras de Pepetela participam da história do país, acompanhando as transformações concretas dessa sociedade, contudo, a decepção com os rumos tomados pelo país converte-se também em elemento poético de um número significativo de trabalhos, nos quais o caráter político de sua escrita domina os enredos e as tramas construídas.

Tecendo em língua portuguesa o seu texto africano, o autor participa da afirmação de
uma identidade própria, [...], e constrói uma obra marcadamente africana, que traz à
tona, sem se tornar estranha a todos os que dessa língua se utilizam, a terra, o povo, a
cultura, o imaginário e as contradições da nação angolana (HILDEBRANDO, 2006,
p.318).

A partir de uma proposta muito característica da escrita pós-colonial, os textos de Pepetela visam tentar dar voz àqueles que foram esquecidos pelo discurso da história colonial e pós-colonial, logo, a utilização dos elementos históricos funcionam como reconstruções de reparação às ações do colonizador ao longo dos séculos da presença portuguesa em Angola. Além disso, a mitificação dos heróis nacionais ou mesmo a criação de heróis idealizados colaboram para a poética política do escritor no projeto de construção do sentimento nacional (OLIVEIRA, 2013 a, 2013b, 2014b).

Como uma forma de reescrita da história, Pepetela consegue refletir o sujeito précolonial, o colonial e o pós-colonial a partir das construções simbólicas e ideológicas presentes nas relações de poder que se tornam atemporais, podendo ser aplicadas nas diferentes épocas da história angolana, pois, o autor busca definir ou redefinir as relações do presente com o passado, questionando certas formas de memória e esquecimento coletivo, destacando os problemas das formações do discurso da história; nesta perspectiva, o trabalho de Pepetela visa confrontar os opostos, como tentativa de reconciliação e exercício de esperança (DRNDARSKA e MALANDA, 2000). 
Reafirmando sua(s) história(s), suas múltiplas fontes, abolindo a hierarquia entre elas, ou seja, dando a um país plural, uma história conjugada no plural [...] Enquanto a ancoragem temporal se faz através de uma periodização que segue o curso da história colonial, a ancoragem espacial se faz através de uma territorialidade simbólica ${ }^{1}$ (DRNDARSKA e MALANDA, 2000, p.116-117. Tradução nossa).

Nessa perspectiva, as personagens principais do romance se distanciam em séculos de história, tomando Luanda, como o território a ser atravessado pelas vidas de Lueji e Lu. De fato, "uma história conjugada no plural" (DRNDARSKA e MALANDA, 2000, p.116-117), em que o resgate histórico da imagem da rainha Lueji em contraste de 400 anos com a dançarina Lu entrelaça duas realidades do país.

Em princípio, tem-se a história da jovem Lueji, coroada rainha depois da morte do pai, constitui o reino de Lunda quatro séculos antes da segunda história, da dançarina Lu que se defronta com os desafios do cotidiano para também se constituir enquanto mulher. Assim, a centralidade do enredo do romance toma as duas protagonistas com o objetivo de dar voz às mulheres da história de Angola que tenderam a ser tangenciadas pela escrita historiográfica.

O reino Lunda é o espaço pautado, basicamente, por tradições de seus ancestrais; tradições essas que impõem limite às personagens, em prol da manutenção do reino. Todos, soberanos, membros do conselho da Lunda e pessoas comuns, têm a obrigação de se submeter às tradições, mas nem todos concordam com isso. Depois da morte de Kondi, o soberano da Lunda, Lueji, sua filha, foi escolhida para substituí-lo (ANTÓNIO, 2015, p.98).

Diante da descrença dos filhos para com a tradição local, Lueji torna-se a próxima na linha de sucessão, sendo vangloriada pelo rei por seu comprometimento em manter as práticas tradicionais do povo Tubungo.

Ela vai fazer o necessário, vai alimentar o meu espírito com as melhores iguarias da Lunda, vai respeitar o meu nome e cultivar o meu prestígio, não vou ser esquecido pelas gerações que se colocam já na bicha do futuro. Kondi será sempre recordado como um homem justo que salvou a Lunda, ao evitar que os filhos varões tomassem o poder para com ele brincar e o destruir (PEPETELA, 2015, p.26).

Configura-se assim o começo do constante desafio de manter o poder, a ela atribuído, frente às ameaças de ataques e ameaças de guerra feitas por seus irmãos Tchinguri (sucessor direito do trono) e Chinyana. Além de um claro conflito pelo poder sobre o povo de Lunda, Lueji defronta-se também pelo difícil dilema de construir sua própria imagem para si mesma e para os outros, uma identidade que pudesse ultrapassar séculos de guerras ao tomar lugar em Luanda, chegaria até a imagem da outra mulher, Lu que enfrentará dificuldades sucessivas para

\footnotetext{
1 "En réaffirmant son/ses histoire(s), leurs multiplex sources, en abolissant la hiérarchie, entre celles-ci, autrement dit, en donnant, à un pays pluriel, une histoire conjuguée au pluriel [..] Autant dire que si l'ancrage temporal se fait à travers une périodisation qui suit le cours de l'histoire coloniale, l'ancrage spatial se fait à travers une territorialité symbolique".
} 
organizar sua apresentação de dança sobre a rainha Lueji e a identidade angolana já no começo do século XXI, na Angola moderna (RAMOS e MELO, 2011).

Lu respirava o ambiente e procurava raízes. Mas eram débeis, apenas alimentadas pelas recordações das falas da avó. Ainda por cima, a cultura dominante era Tchokue, assim como a população. Gente lunda era minoria, reduzida a grupos cercados e isolados. Muitas vezes nem o próprio conservador conseguia separar as duas culturas. E ela se preocupara com a origem dos muquixes, ridículo! Se as próprias estátuas de Tchibinda Ilunga e de Lueji, raridades existentes no museu, erram indubitavelmente de arte tchokue... (PEPETELA, 2015, p.336).

A referência às questões de origem do povo angolano constitui-se como uma necessidade de revelar-se às personagens Lueji e posteriormente Lu. Conhecer a sua própria história torna-se fundamental para a dançarina Lu, pois, a busca por sua ancestralidade a levaria até a grande rainha Lueji, como um exercício de reconstituição histórica. Para Ramos e Melo (2011, p.182) "Pepetela atualiza e projeta o futuro pelo viés do mito de origem, num dos momentos de maior acirramento da guerra civil angolana, quando a nação, pela qual lutou sua geração, ameaçava deixar de existir”. Em outras palavras, a tentativa de Pepetela de fortalecer o mito de origem do povo angolano está estritamente ligada à necessidade de se pensar em um projeto político para o futuro do país, marcado pelas guerras civis durante várias décadas.

Desse modo, Lueji, o nascimento de um império (2015) pode ser tomado como um romance histórico, pela releitura constante da história de Angola e pelo trabalho com o tema da constituição da nacionalidade e das raízes de identidade na nação. Porém, pode-se afirmar que Pepetela atribui um caráter político ao romance no momento em que se utiliza dos fatos históricos para discutir os conflitos pelo poder político do país no período pós-independência (SANTOS, 2014). Trata-se de um recurso de criação constante em obras do autor, uma vez que em várias obras a releitura da história servia como material de reflexão sobre as condições atuais do país e principalmente às contradições do projeto político de independência pós-colonial que levaram o país ao destrutivo conflito armado (OLIVEIRA, 2013a).

E Lueji reinava sozinha, com os conselhos de quem ela escolhia, Ilunga, Kumbana, Majinga, Kakongo e poucos mais. Mas o espírito de Kondi continuava a recursar o novo costume que lhe queriam impor, era a única nuvem negra.

Yanvu ia fazer a circuncisão. Acompanhava a mãe para todo o lado e até assistia às reuniões do Conselho, para se preparar. (PEPETELA, 2015, p.445).

Como respeito às regras, Lueji, mesmo não totalmente convencida sobre as habilidades do filho para tomar o poder do reino Lunda, está pronta para atribuir ao herdeiro direto o posto de líder dos lundos após governar seu povo com força e dedicação. Assim, nesse jogo de retornos e avanços no tempo, a história de Angola se constrói e se reconstrói por meio de um mito de origem único que coloca a rainha Lueji, como imagem central do legado construído por 
uma mulher resistente no governo local e que soube lidar com os conflitos pelo poder, na tentativa de manter a qualquer preço unidade do seu povo. Contudo, Santos (2014) destaca a manutenção de privilégios por membros do reinado de Lueji, como uma analogia aos projetos políticos pós-independência em que se acreditava numa real modificação da ordem social e política do país.

Em contraponto a crítica política, o romance também resgata uma discussão sobre o processo de escrita da história de Angola. Para Dias (2015), recontar a história do país por meio da dança destaca o importante papel da personagem $\mathrm{Lu}$, enquanto representante das artes, para estabelecer um diálogo com o discurso científico da escrita da história. A personagem entende as configurações do mito e da história, o papel das ideologias na composição dos discursos e até por isso mesmo, ressalva a relevância da sua arte na unificação da sociedade angolana.

Já no projeto contemporâneo de recontar a história da rainha lunda, Lu encontra problemas em organizar o roteiro do espetáculo devido às inconsistências históricas reclamadas pelo historiador Herculano.

-É certo que há versões contraditórias. Como tudo na tradição oral. Cada grupo deforma uma versão em função dos seus interesses mais ou menos imediatos, isto é, a versão tradicional é sempre ideológica, justifica ou o poder que se tem ou o poder que se quer obter. Ou o porquê de se ter perdido o poder. Depurar a versão da ideologia que nela está presente, eis o trabalho da ciência histórica. E isso só se pode fazer comparando as diferentes versões e situando cada uma no seu contexto histórico (PEPETELA, 2015, p.357).

Por fim, apesar de todas as dificuldades de recontar a história da rainha Lueji, Lu pôde enfim dar início aos ensaios para seu espetáculo, aceitando os meandros da escrita ideológica e das inúmeras versões da mesma verdade.

\section{CONSIDERAÇõES FINAIS}

De maneira sintética, o estudo comparado aqui empreendido foi capaz de fornecer importantes informações sobre a composição narrativa africana, em especial a formação do romance contemporâneo, como gênero literário mais difundido nas últimas décadas no continente. A partir de reflexões sobre abordagens temáticas e estrutura do romance, buscou-se obter elementos composicionais de aproximação entre as obras, a fim de construir um quadro comparativo relevante para os objetivos da investigação. Desse modo, com o propósito de pensar as características do romance no contexto africano, o trabalho apresentou inicialmente algumas das principais configurações da representação literária contemporânea, a fim de estabelecer um paralelo comparativo com a produção ficcional africana. Buscou-se, assim, refletir sobre os mecanismos criativos utilizados pelos escritores africanos para discutir a 
história da África e as particularidades dos processos de formação dos estados nacionais, e evidentemente, como esses eventos se refletiam no material literário ficcional.

Inicialmente, por meio da análise do romance Um rio chamado tempo, uma casa chamada terra (2003) de Mia Couto foi possível observar a enorme conexão que a literatura possui com o passado de conflito do continente, suas principais transformações culturais e sociais em que a tradição e a modernidade se chocam constantemente, como uma tentativa de construir uma imagem híbrida sobre as perspectivas para o futuro do continente.

Em Hibisco Roxo (2011) de Chimamanda Adichie, apesar da forte referência à história política da Nigéria, e de certa maneira, a vários outros países da África, a discussão sutil sobre o papel da mulher na literatura e na sociedade africana tornou-se um elemento imprescindível para se oferecer qualquer perspectiva teórica sobre o romance na atualidade. A partir de um enredo em que as mulheres se tornam as protagonistas das ações, tem-se uma mudança muito significativa para as literaturas africanas como um todo. Assim, não somente a escrita feminina se fortalece como também personagens importantes da história da África, silenciadas pelo empreendimento colonial e posteriormente pelos conflitos armados, e puderam ganhar voz e um discurso, diante de todos os impactos discursivos da escrita consagrada da história.

Em seguida, a obra Lueji: o nascimento de um império (2015) de Pepetela forneceu às análises um reconhecido instrumento moderno de criação literária, ou seja, a releitura dos fatos históricos e reconstrução de eventos através do mito e do resgate de personagens importantes da história nacional. Trata-se de um mecanismo muito comum aos países africanos, uma vez que a necessidade de conhecer a fundo a própria história faz com que os romances possuam determinados elementos históricos fundamentais para a formação de identidades nacionais, contribuindo diretamente para a reconstrução cultural pós-colonial. Enfim, trata-se de um panorama singelo para se discutir as literaturas africanas, como um todo, mas contribui enormemente para a constituição de um material reflexivo robusto e plural, podendo auxiliar no acesso de novos pesquisadores ao universo literário africano.

\section{REFERÊNCIAS}

ADICHIE, Chimamanda N. Hibisco Roxo. $2^{\mathrm{a} e d . ~ S a ̃ o ~ P a u l o: ~ c o m p a n h i a ~ d a s ~ L e t r a s, ~} 2011$.

ANN, Ibeku I. Adichie's Purple Hibiscus and the Issue of Feminism in African Novel. Journal of Literature and Art Studies, Vol. 5, No. 6, 426-437, June- 2015.

ANTÓNIO, Mateus P. P. Romance e realidade em Lueji, o nascimento de um império, de Pepetela. Cadernos CESPUC, Belo Horizonte, nº 27, 2015. 
BAKHTIN, Mikhail. Questões de literatura e de estética. São Paulo: Hucitec, 2010.

BERGSON, Henri. Memória e vida. São Paulo: Martins Fontes, 2006.

CANDIDO, Antonio. Literatura e Sociedade: Estudos de Teoria e História Literária. 11ed. Rio de Janeiro: Ouro sobre Azul, 2000

CAMPOS, Juliana S. As manipulações das etnicidades como forma de controle, exploração e alienação em Hibisco Roxo de Chimamanda Ngozi Adichie. Revista Crioula USP, No. 16 Dezembro de 2015.

CARVALHAL, Tania F. Literatura comparada. São Paulo: Ática, 2006.

CHAVES, Rita. Angola e Moçambique: experiência colonial e territórios literários. Cotia, SP: Ateliê Editorial, 2005.

CHAVES, Rita A formação do romance angolano. São Paulo: Lato Senso, 1999.

CHAVES, Rita; MACÊDO, Tania (Org.) Portanto...Pepetela. São Paulo: Ateliê Editorial, 2009.

COSTA LIMA, Luiz. História, ficção, literatura. $2^{\mathrm{a}}$ ed. São Paulo: Companhia das Letras: 2006.

DIAS, Mariana S. Pepetela e a (re)escrita de Angola: tensionamentos entre memória coletiva e discurso historiográfico em Yaka e Lueji - o nascimento de um império. Revista de

Literatura, História e Memória VOL. 11 - № 18, 2015.

DRNDARSKA, Dea; MALANDA, Ange-Séverin. Pepetela et l'écriture du mythe et de

l'histoire. Paris: L'Harmattan, 2000.

FIORIN, José L. Linguagem e ideologia. 7ed. - São Paulo: Editora Ática, 2003

FISCHER, Ernst. A necessidade da arte. Rio de Janeiro: Zahar, 1983.

GOMES, Júnio V. Hibisco Roxo. Revista Trilhas da História. Três Lagoas, v.3, nº5 jul-dez, 2013.

HILDEBRANDO, Antonio. A revolta da casa dos ídolos: renovação e tradição. In: CHAVES, Rita e MACÊDO, Tania (Org.) Portanto... Pepetela. São Paulo: Ateliê Editorial, 2009

IFECHELOBI, J.N. Feminism: Silence and Voicelessness as Tools of Patriarchy in Chimamanda Adichie's Purple Hibiscus. International Association of African Researchers and Reviewers, VOL. 35, SEPTEMBER, 2014.

KUNDERA, Milan. A arte do romance. Rio de Janeiro: Nova Fronteira, 1988.

LEITE, Ana M. Literaturas africanas e formulações pós-coloniais. Lisboa: Colibri, 2003.

LUKÁCS, Georg. A teoria do romance. São Paulo: Duas cidades, 2000. 
MAQUÊA, Vera. A escrita nômade do presente: literaturas de língua portuguesa. São Paulo: Arte \& Ciência, 2010.

MORIN, Edgar. A cabeça bem-feita: repensar a reforma, reformar o pensamento. Trad. Eloá Jacobina. 8 ed. - Rio de Janeiro: Bertrand Brasil, 2003

MORIN, Edgar. Os sete saberes necessários à educação do futuro. Trad. Catarina E. F. da Silva e Jeanne Sawaya. 2 ed. - São Paulo: Corteza, 2000.

MORIN, Edgar. O cinema ou o homem imaginário. Trad. António-Pedro Vasconcelos. Lisboa: Moraes Editores, 1970

MÜLLER, F.O. O florescer das vozes na tradução de purple hibiscus,de Chimamanda Ngozi Adichie. Tese (Mestrado em estudo da tradução) - Faculdade de Letras, Universidade de Brasília, p. 26. 2017.

OLIVEIRA, Adilson V. O teatro político angolano em A revolta da casa dos ídolos, de Pepetela. Dissertação (Mestrado em Estudos Literários) PPGEL, Universidade do Estado de Mato Grosso, 2013a.

OLIVEIRA, Adilson V. Literatura e história: estudo sobre A revolta da Casa dos Ídolos e Bom dia, camaradas. Revista Athena. Vol. 04, nº 1,2013 b.

OLIVEIRA, Adilson V. Teoria do romance moderno em "A insustentável leveza do ser" de Milan Kundera. Revista Athena. Vol. 7 n², 2014a.

OLIVEIRA, Adilson V. Literatura e política: as contradições do socialismo em "O planalto e a estepe". Revista Ecos vol. 16, Ano XI; nº 01, 2014 b.

PETROV, Vanessa P. A problemática da identidade cultural em Um Rio chamado Tempo, Uma Casa chamada Terra, de Mia Couto, e Le Ventre de l'Atlantique, de Fatou Diome. Lisboa: CLEPUL, 2014.

PONTES, Daniele S. A morte e a ancestralidade: em Um rio chamado tempo, uma casa chamada terra. Monografia (Graduação em Letras). Centro de Humanidade. Universidade Estadual da Paraíba, Guarabira, 2014.

RAMOS, Dernival V. ; MELO, Márcio A. Nação e narrativa em Pepetela. Revista Locus, Juiz de Fora, v.17, nº 1 , p.173-188, 2011.

REUTER, Yves. Introdução à análise do romance. 2ed. São Paulo: Martins Fontes, 2004.

SANTOS, Donizeth. Lueji, o nascimento dum império: um romance alegórico e político.

Revista Mulemba. Rio de Janeiro: UFRJ, V.1, n. 11, pp. 35- 45, jul./dez. 2014

WATT, Ian. A ascensão do romance. São Paulo: Companhia das letras, 2010.

Recebido em: 22 de maio de 2018. Aprovado em: 27 de outubro de 2018. 